\begin{tabular}{|c|c|c|c|}
\hline $\begin{array}{l}\text { ReSEARCH } \\
\text { ArtiCle }\end{array}$ & $\begin{array}{r}\text { ADVANCE RESEARCH JOURNAL O } \\
\text { volume } 7 \mid \text { Issue } 2 \mid \text { December, 2016 } \mid 249-251\end{array}$ & $\begin{array}{l}\text { F SOCIAL SCIENCE } \\
\text { e ISSN-2231-6418 }\end{array}$ & \\
\hline $0=$ & DOI: 10.15740/HAS/ARJSS/7.2/249-251 & Visit us : www.researchjournal.co.in & \\
\hline
\end{tabular}

\title{
Role perception of women extension workers of the state agricultural department
}

M.R. Rathod, S.U. Mokhale* and A.N. Deshmukh

Department of Extension Education, Shri Shivaji Agriculture College, AMRAVATI (M.S.) INDIA

\section{ARTICLE INFO :}

$\begin{array}{lll}\text { Received } & : & 24.09 .2016 \\ \text { Revised } & : & 07.11 .2016 \\ \text { Accepted } & : & 20.11 .2016\end{array}$

KEY WORDS :

Women extension workers, Perception, Constraints, Agricultural department, Key person

\section{HOW TO CITE THIS ARTICLE :}

Rathod, M.R., Mokhale, S.U. and Deshmukh, A.N. (2016). Role perception of women extension workers of the state agricultural department. Adv. Res. J. Soc. Sci., 7 (2) : 249-251, DOI: 10.15740/ HAS/ARJSS/7.2/249-251.

*Author for correspondence

\begin{abstract}
The present study on role perception of women extension workers of the state agricultural department was conducted in the year 2015-16 in four talukas of Amravati district. Result obtained after analysis have been summarized as below. Findings of relational analysis observed that education, training received, type of family, family background, land holding, annual income and job satisfaction were positive and significant correlation with role perception. Whereas marital status, distance from home and length of service experience had shown non-significant correlation with role perception. More quantum of office work than the technical job, non-availability of audio- visual aids, lack of co - operation from other department, non-availability of financial incentives for additional work and non - availability of require input were the major constraints faced by women extension workers.
\end{abstract}

